\title{
ANALISIS AKUNTANSI PENDAPATAN KONTRAK KONTRAK BERDASARKAN PSAK NO.34 PADA PT. SAMUDRA JAYA LESTARI
}

\author{
${ }^{1}$ Neneng Arum Mia, ${ }^{2}$ Sardiyo, ${ }^{3}$ Eri Triharyati \\ 1,2,3 Fakultas Ekonomi dan Bisnis, Universitas Bina Insan \\ e-mail : ${ }^{1}$ armi300498@gmail.com, ${ }^{2}$ sardiyo@ univbinainsan.ac.id, ${ }^{3}$ Eri_triharyati@ univbinainsan.ac.id
}

\begin{abstract}
The purpuse of this study is to determine the recognition of income applied by PT.Samudra Jaya lestari whether it is in accordance with PSAK No.34 (Revision 2015). Revenue is one of the important elements in information of the elemenst related to the size of the profit earned by company. The method used in this research is in the form of financial statements and work contract letters of PT.Samudra Jaya Lestari and other data in form of literature, articles, journals and websites on the internet.The result of research conducted, namely PT.Samudra Jaya Lestari in applying the income recognition method are not in accordance with the financial statement accounting standards, namely PSAK No.34 regarding constructionservices because PT. Samudra Jaya Lestari has not been consistent in using the income recognition method every year, which should be used in accordance with the provisions that have been applied in PSAK No. 34 concerning construction servive revenue.
\end{abstract}

Keyword : Income Accounting Article 34, Construction Services Revenue, Construction Service

\begin{abstract}
ABSTRAK
Tujuan penelitian ini yaitu untuk mengetahui pengakuan pendapatan dan beban serta pengungkapan pendapatan dan beban yang diterapkan PT.Samudra Jaya Lestari apakah sudah sesuai dengan PSAK No.34 (Revisi 2015). Pendapatan merupakan salah satu unsur penting dalam pembentukan laba perusahaan dan merupakan salah satu unsur yang berhubungan dengan besar kecilnya laba yang diperoleh setiap perusahaan.Metode yang digunakan dalam penelitian ini adalah metode kualitatif. Jenis data yang digunakan yaitu berupa laporan keuangan dan surat perjanjian kontrak kerja PT.Samudra Jaya Lestari dan data lainnya berupa literatur, artikel, jurnal dan situs di internet.Hasil penelitian yang telah dilakukan yaitu PT.Samudra Jaya Lestari dalam menerapkan metode pengakuan pendapatan belum sesuai Standar Akuntansi Pernyataan Keuangan yaitu PSAK No.34 tentang jasa konstruksi karena PT.Samudra Jaya Lestari belum konsisten dalam penggunaan metode pengakuan pendapatan setiap tahunnya, yang seharusnya digunakan sesuai ketentuan yang telah diberlakukan dalam PSAK No.34 tentang pendapatan jasa konsttruksi.
\end{abstract}

Kata kunci : Akuntansi Pendapatan, PSAK No.34, Jasa Konstruksi, Pendapatan Jasa Konstruksi 


\section{PENDAHULUAN}

Pembangunan merupakan sudut pandang penting yang mempengaruhi majunya suatu wilayah (negara) dan kesejahteraan masyarakat. Seiring dengan perkembangan perekonomian di masa yang serba canggih seperti sekarang ini, Pemerintah diminta agar bisa menciptakan kegiatan pembangunan nasional untuk meningkatkan kesejahteraan rakyat. Peranan seluruh elemen masyarakat ikut berperan dalam menciptakan organisasi khususnya perusahaan konstruksi (jasa konstruksi). Tujuan didirikannya suatu organisasi yaitu adanya tujuan tertentu yang ingin dicapai .Setiap organisasi memiliki tujuanm yang berbeda-beda tergantung dari jenis organisasinya. Terdapat dua jenis organisasi berdasarkan tujuannya, yaitu organisasi yang bertujuan untuk memperoleh laba (oriented laba) dan ada juga organisasi yang bertujuan tanpa mencari laba (non profit). Dari dua jenis organisasi tersebut perusahaan konstruksi masuk dalam jenis perusahaan yang didirikan dengan tujuan untuk memperoleh laba yang sebesar-besarnya dari kegiatan usaha yang dilakukan. PSAK No.34 revisi 2015 tentang pendapatan kontrak dibagi menjadi: (1) Pendapatan yang telah disetujui diawal yang terdapat dalam kontrak; dan (2) penyimpangan yang dilakukan selama pengerjaan proyek, permintaan ganti rugi dan pembayaran bonus: (a) dalam hal ini yang memungkinkan agar menghasilkan pendapatan; dan (b) dapat teruji kebenarannya [1]. Unsur penting yang dapat mempengaruhi pembentukan laba perusahaan salah satunya yaitu pendapatan. Selain itu, pendapatan juga merupakan salah satu unsur yang dapat mempengaruhi besar kecilnya laba yang didapatkan oleh perusahaan [2]. Perusahaan yang bergerak dibidang pemberian jasa dan barang dapat dikatakan berhasil dapat diukur dari besarnya laba yang diperoleh perusahaan dalam periode tertentu. Setiap perusahaan wajib mempertanggung jawabkan kinerja nya dalam suatu periode yaitu pada akhir periode untuk dilaporkan kepada pihak yang berkepentingan dalam bentuk laporan keuangan. Dalam melakukan penyusunan dan penyajian laporan keuangan sebaiknya dilakukan secara tepat dan dapat diuji. Laporan keuangan yang disajikan secara tepat dan dapat diuji bertujuan untuk memberikan gambaran gambaran dan informasi tentang keuangan perusahaan yang sebenarnya. Oleh karena itu,terdapat masalah penting yang disebabkan oleh pendapatan yaitu tentang keberhasilan suatu perusahaan yang dapat diukur dari tingkat pendapatan agar menjadi bahan evaluasi bagi manajemen perusahaan untuk mengambil tindakan rencana kerja untuk tahun berikutnya.

Pernyataan Standar Akuntansi No.34 menyatakan bahwa metode persentase penyelesaian merupakan pengakuan pendapatan memperhatikan tingkat penyelesaian kegiatan kontrak. Dalam suatu kontrak terdapat biaya yang berhubungan dengan aktivas kelanjutan pada kontrak tersebut. Aset merupakan biaya kontrak yang kemungkinan dapat dikembalikan. Jumlah yang dapat ditagih oleh pelanggan dan dapat digolongkan sebagai aktivitas dalam proses pengerjaan kontrak [1].

Berdasarkan Pernyataan Akuntansi Keuangan PSAK NO.34, Pendapatan yang terdapat dalam kontrak diakui sebagai kontrak dan biaya yang terdapat dalam kontrak diakui sebagai beban yang disesuaikan dengan tingkat penyelesaian kontrak pada tanggal neraca (percentage of completion).Itulah hasil dari pendapatan yang dapat diestimasi secara andal [1].

Menurut Pernyataan Standar Akuntansi (PSAK No.34 Revisi 2015). Jangka waktu dalam menyelesaikan suatu proyek jangka panjang suatu perusahaan yang bergerak dibidang jasa yaitu ada yang kurang dari satu periode akuntansi dan ada yang lebih dari satu periode akuntansi. Pendapatan terdiri dari nilai pendapatan semua yang disetujui dalam perjanjian,permintaan ganti rugi , dan pembayaran bonus apabila pendapatan diukur secara tepat dan teruji [1]. 
Pengukuran pada nilai wajar dari imbalan dan dapat diterima yaitu besarnya pendapatan. Beragam ketidakpastian yang mempengaruhi aktivitas kegiatan kontrak pada masa yang akan datang dapat mempengaruhi pengukuran pendapatan kontrak. Jumlah pendapatan pada periode satu ke periode berikutnya perlu dilakukan revisi agar sesuai dengan realisasi dan hilangnya ketidakpastian.

Hasil dari proses akuntansi yang dapat digunakan sebagai tolak ukur dalam berkomunikasi antara data keuangan dengan kegiatan suatu perusahaan dengan pihak-pihak yang mempunyai kepentingan merupakan laporan keuangan. Bagian dari laporan keuangan yaitu meliputi laporan laba rugi, neraca, laporan perubahan ekuitas, laporan arus kas, dan laporan catatan atas laporan keuangan. Ketepatan penyajian laporan keuangan merupakan bagian penting bagi kelompok yang membutuhkannya, baik kelompok ekstern maupun kelompok intern. Untuk menunjang ketepatan dalam menyajikan laporan keuangan, terutama laporan perhitungan laba rugi, maka perusahaan perlu menetapkan kebijakan metode pengakuan pendapatan yang tepat. Kesalahan perusahaan dalam menerapkan metode pengakuan pendapatan dapat menyebabkan hasil perhitungan laba rugi perusahaan menunjukkan nilai yang tidak wajar, sehingga dapat menyesatkan para pengguna laporan keuangan tersebut, karena pengambilan keputusan berdasarkan laporan keuangan tersebut.

\section{TINJAUAN PUSTAKA}

Menurut PSAK No.34 Revisi 2015 paragraf 1 pernyataan ini harus diterapkan pada akuntansi untuk kontrak konstruksi di dalam laporan keuangan. Paragraf 2, Berikut adalah pengertian istilah yang digunakan dalam pernyataan ini [1]:

1. Konstruksi adalah Kontrak suatu kontrak yang dinegosiasi secara khusus untuk konstruksi suatu aset atas suatu kombinasi aset yang berhubungan erat satu sama lain atau saling tergantung dalam hal rancangan, teknologi dan fungsi atau tujuan atau penggunaan pokok.

2. Kontrak Harga Tetap adalah kontrak konstruksi dengan syarat bahwa kontraktor telah menyetujui nilai kontrak yang telah ditentukan, atau tarif tetap yang telah ditentukan per unit output, yang dalam beberapa hal tunduk pada ketentuan-ketentuan kenaikan biaya.

3. Kontrak Biaya-Plus adalah kontrak konstruksi di mana kontraktor mendapatkan penggantian untuk biayabiaya yang telah diizinkan atau telah ditentukan, ditambahkan imbalan dengan persentase terhadap biaya atau imbalan tetap.

4. Suatu klaim adalah jumlah yang diminta kontraktor kepada pemberi kerja atau pihak lain sebagai penggantian untuk biaya-biaya yang tidak termasuk dalam nilai kontrak. Klaim dapat timbul, umpamanya, dari keterlambatan yang disebabkan oleh pemberi kerja, kesalahan dalam spesifikasi atau rancangan, dan perselisihan penyimpangan dalam pengerjaan kontrak.

5. Retensi adalah jumlah termin (progres billings) yang tidak dibayar hingga pemenuhan kondisi yang ditentukan dalam kontrak untuk pembayaran jumlah tersebut atau hingga telah diperbaiki.

6. Termin (progres billings) adalah jumlah yang ditagih untuk pekerjaan yang dilakukan dalam suatu kontrak naik yang telah dibayarkan ataupun yang belum dibayarkan oleh pemberi kerja.

\subsection{Metode Pengakuan Pendapatan dan Beban}

Menurut PSAK No.34 (Revisi 2015) paragraf 23 menjelaskan bahwa pengakuan pendapatan dan beban dengan memerhatikan penyelesaian suatu kontrak sering disebut sebagai metode persentase penyelesaian (percentage of completion). Menurut metode ini, pendapatan kontrak dihubungkan dengan biaya kontrak yang terjadi dalam mencapai 
tahap penyelesaian tersebut, sehingga pendapatan, beban, dan laba yang dilaporkan dapat diatribusikan menurut penyelesaian pekerjaan secara proporsional. Metode ini memberikan informasi yang berguna mengenai cakupan aktivitas kontrak dan kinerja selama suatu periode [1].

Paragraf 24 metode persentase penyelesaian (Percentage of completion), pendapatan kontrak diakui sebagai pendapatan dalam laporan laba rugi dalam periode akuntansi dimana pekerjaan dilakukan. Biaya kontrak biasanya diakui sebagai beban dalam laporan laba rugi dalam periode akuntansi dimana pekerjaan yang berhubungan dilakukan. Namun, setiap ekspektasi selisih lebih total biaya kontrak segera diakui sebagai beban sesuai dengan paragraf 34 [3]. Metode per metode, secara bertahap agar lebih lengkap dan bisa diterapkan dalam pekerjaan yang sesungguhnya.

1. Pengakuan Pendapatan Dengan Metode Akrual (Accrual Method),

Pengakuan pendapatan dengan pendekatan akrual termasuk yang paling mendasar, sehingga paling banyak diterapkan di berbagai jenis usaha dalam berbagai skala. Pada dasarnya metode akrual menggunakan pendekatan yang sama persis seperti yang sudah disampaikan di tulisan sebelumnya, yaitu “ Ketentuan Dasar Pengakuan Pendapatan", KECUALI ketentuan IAS yang ke-2 (recognition at time of payment) yang cenderung mengarah ke cash basis. Sehingga, sepanjang ketentuan-ketentuan dasar tersebut telah terpenuhi, maka suatu pendapatan sudah boleh diakui. Hal yang tak kalah penting untuk diketahui, sehubungan dengan penerapan metode ini adalah adanya beban dan biaya yang diakui untuk disandingkan dengan pendapatan yang dihasilkan dalam periode yang sama meskipun invoice tagihannya belum datang dari supplier atau vendor.

2. Pengakuan Pendapatan Dengan Metode Kas ( Cash Method)

Dengan menggunakan metode kas artinya perusahaan hanya mengakui pendapatan bila kas (atas penyerahan barang atau jasa) sudah diterima. Ini metode paling tua yang sudah ada sejak sebelum Prinsip Akuntansi Berterima Umum (GAAP) ada. Dan oleh GAAP (di Indonesia PSAK), pengakuan pendapatan dengan metode kas tidak diijinkan. Itu masa lalu. Saat ini, standarakuntansi kita telah mengakui IFRS. IAS 18, " Revenue" pada ketentuan kedua menyebutkan bahwa: pendapatan belum boleh diakui sampai dengan memperoleh kepastian mengenai kas yang akan diterima meskipun barang telah diserahkan. Sepertinya, ketentuan ini mengarahkan agar pengakuan pendapatan kembali ke metode kas. Namun sampai saat ini JAK belum memperoleh informasi yang cukup apakah memang demikian maksudnya. Jika iya, tentu ini akan menjadi kontra terhadap ketentuan pengakuan pendapatan versi GAAP di waktu-waktu yang lalu. Yang menekankan pentingnya metode akrual. (Note: lebih lengkap mengenai ketentuan dasar pengakuan pendapatan di tulisan sebelumnya)

\section{a. Pengakuan Pendapatan Metode \\ Pencicilan Penjualan (Installment Sales Method)}

Metode pencicilan diterapkan untuk pengakuan pendapatan yang diperoleh dari penjualan yang sistem pembayaran dicicil yang dalam ketentuan IFRS dikatakan mengandung tingkat ketidakpastian (uncertainties) yang tinggi.

b. Metode Persentase Penyelesaian
(Percentage Of Completion Method). Metode Persentase Penyelesaian diterapkan untuk perusahaan-perusahaan kontraktor yang menangani proyek-proyek konstruksi. Hingga bisa diserahkan kepada pemberi kontrak (pemesan), proyek-proyek konstruksi biasanya membutuhkan waktu yang panjang (lebih dari satu tahun buku). Oleh karena itu pemesan biasanya melakukan pembayaran dengan 2 cara yaitu:

1) Ada yang melakukan pembayaran sekaligus, biasanya untuk proyek yang membutuhkan waktu penyelesaian yang relatif singkat (satu hingga dua tahun) 
2) Ada juga yang melakukan pembayaran secara bertahap sesuai dengan tingkat perkembangan penyelesaian proyek.

Secara umum, pedoman untuk pengakuan pendapatan sangat luas. Prinsip pengakuan pendapatan memberikan perusahaan pengetahuan bahwa mereka harus mengetahui pendapatan (1) pada saat pendapatan tersebut telah direalisasikan dan (2) pada saat telah diterima/didapatkan. Oleh karena itu, pengakuan pendapatan yang benar melibatkan 3 syarat:

1) Pendapatan direalisasikan pada saat sebuah perusahaan melakukan pertukaran barang dan jasa untuk mendapatkan cash.

2) Pendapatan dapat direalisasikan ketika aset yang diterima perusahaan dari pertukaran (exchange) siap untuk ditukarkan menjadi sejumlah uang.

3) Pendapatan dihasilkan/didapatkan ketika sebuah perusahaan telah menyelesaikan apa yang harus dikerjakan untuk mendapatkan keuntungan, ketika earning proses selesai.

Pengakuan pendapatan perusahaan kontraktor ada dua metode yaitu [4]:

1) Metode persentase penyelesaian merupakan metode pendapatan dan laba kotor diakui pada setiap periode, didasarkan atas kemajuan dalam pembangunan, yaitu persentase dari penyelesaian.

2) Metode kontrak selesai adalah metode yang pendapatan dan laba kotor diakui hanya pada waktu kontrak diselesaikan.

Berdasarkan pendapatan di atas dapat disimpulkan bahwa metode pengakuan pendapatan yaitu metode persentase penyelesaian merupakan metode yang pendapatan dan laba kotor diakui pada setiap periode, didasarkan atas kemajuan dalam pembangunan, yaitu persentase dari penyelesaian dan metode kontrak selesai adalah metode yang pendapatan dan laba kotor diakui hanya pada waktu kontrak diselesaikan.

Paragraf 28 menjelaskan tahap penyelesaian suatu kontrak dapat ditentukan dalam berbagai cara. Perusahaan menggunakan metode mengukur secara andal pekerjaan yang dilakukan. Tergantung pada sifat kontrak, metode tersebut antara lain meliputi:

1) Proporsi biaya kontrakuntuk pekerjaan yang dilaksanakan sampai tanggal total biaya yang diestimasi;

2) Survei atas pekerjaan yang telah dilaksanakan;

3) Penyelesaian suatu bagian secara fisik dari pekerjaan kontrak.

\subsection{Pengertian Pengakuan Pendapatan dan Beban}

Menurut PSAK No.34 (Revisi 2015) tentang pengakuan pendapatan bila hasil (outcome) kontrak kontrak dapat diestimasi secara andal, pendapatan kontrak dan biaya kontrak yang berhubungan dengan kontrak konstruksi diakui masing-masing sebagai pendapatan dan beban dengan memperhatikan tahap penyelesaian aktivitas kontrak pada tanggal neraca (percentage of completion).Taksiran rugi (expected loss) pada kontrak konstruksi tersebut harus segera diakui sebagai beban sesuai dalam paragraf 34, yaitu bila besar kemungkinan terjadi bahwa total biaya kontrak akan melebihi total pendapatan kontrak, taksiran rugi(expected loss) harus segera diakui sebagai beban [1].

Pengakuan pendapatan menurut Ikatan Akuntan Indonesia dalam pernyataan Standar $\begin{array}{lll}\text { Akuntansi Keuangan (PSAK) No.23 } & \end{array}$ menjelaskan kapan suatu pendapatan diakui sebagai:

1) Pendapatan dari transaksi penjualan produk diakui pada saat tanggal penjualan, biasanya merupakan tanggal penyerahan kepada produk pelanggan.

2) Pendapatan atas jasa yang diberikan oleh perusahaan jasa diakui pada saat tersebut telah dilakukan dapat dibuat fakturnya.

3) Imbalan yang diperoleh atas penggunaan aktiva sumber-sumber ekonomi perusahaan oleh pihak lain, seperti pendapatan uang, dan royalti diakui sejalan dengan berlalunya waktu atau 
pada saat digunakan aktiva yang bersangkutan.

4) Pendapatan dari penjualan aktiva diluar barang dagangan seperti penjualan aktiva tetap atau surat berharga diakui pada saat tanggal penjualan

Pendapatan harus diukur dengan nilai wajar imbalan yang diterima atau yang dapat diterima, pada umumnya imbalan tersebut berbentuk kas atau setara kas. Bila arus kas atau setara kas ditangguhkan, nilai wajar dari imbalan tersebut mungkin kurang dari jumlah nominal dari kas yang diterima atau yang dapat diterima. Berkaitan dengan masalah pendapatan tersebut, ada beberapa hal yang perlu diketahui tentang prinsip pengakuan pendapatan harus diakui dalam laporan keuangan ketika:

1) Pendapatan dihasilkan, dan

2) Pendapatan direalisasikan atau direalisasikan.

Pengakuan suatu jumlah rupiah dalam akuntansi pada umumnya didasarkan pada konsep objektivitas yaitu bahwa jumlah rupiah tersebut pihak independen dalam pengukurannya. Dengan kata lain harus ada bukti yang cukup objektif untuk dapat mengakui. Bila kondisi atau kejadian tertentu menjadikan kriteria tersebut dipenuhi maka kondisi atau kejadian tersebut akan memicu pengakuan pendapatan.

Menurut PSAK No.23 menyebutkan sebagai berikut kriteria pengakuan pendapatan biasanya diterapkan secara terpisah kepada setiap transaksi, namun dalam keadaan tertentu adalah perlu untuk menerapkan kriteria pengakuan tersebut kepada komponenkomponen yang dapat diidentifikasikan secara terpisah dari suatu transaksi tunggal, agar mencerminkan substansi dari transaksi tersebut.

Berdasarkan pendapat diatas, dapat disimpulkan bahwa pengakuan pendapatan merupakan pendapatan dari transaksi penjualan produk diakui pada saat tanggal penjualan, biasanya merupakan tanggal penyerahan produk kepada pelanggan, pendapatan atas jasa diakui pada saat jasa tersebut telah dilakukan dapat dibuat fakturnya, imbalan yang diperoleh atas penggunaan aktiva sumber-sumber ekonomi perusahaan oleh pihak lain, seperti pendapatan bunga, dan royalti yang diakui sejalan dengan berlalunya waktu atau pada saat digunakan aktiva yang bersangkutan, dan pendapatan dari penjualan aktiva diluar barang dagangan seperti penjualan aktiva tetap atau surat berharga diakui pada saat tanggal penjualan.

\subsection{Penelitian Terdahulu}

Hasil penelitian ini didukung oleh penelitian yang dilakukan oleh Rahayu dan Kardinal (2013) dan juga penelitian Hasnawati, Firman Menne, dan Chahyono (2016) dimana haasil penelitian mengungkapkan bahwa perusahaan menggunakan metode kontrak selesai dalam mengakui pendapatan proyek jangka panjang. Sehingga membuat laba perusahaan pada tahun tertentu kecil dan meningkat pada tahun berikutnya karena proyek yang dikerjakan telah selesai sepenuhnya, sehingga belum sesuai PSAK No.34 dan tidak mencerminkan keadaan laporan keuangan yang sebenarnya yang dapat mengakibatkan kesalahan manajemen dalam pengambilan keputusan [5];[6]. 


\begin{tabular}{|c|c|c|c|c|}
\hline & \multicolumn{4}{|c|}{ Revenue Recognition Classified by Type of Transaction } \\
\hline & Chapter 18 & Chapter 18 & Chapter 14 \& others & Chapter 10 \\
\hline $\begin{array}{l}\text { Type of } \\
\text { Transaction }\end{array}$ & $\begin{array}{l}\text { Sale of } \\
\text { product from } \\
\text { inventory }\end{array}$ & $\begin{array}{l}\text { Rendering } \\
\text { a service }\end{array}$ & $\begin{array}{l}\text { Permitting } \\
\text { of an } \\
\text { assent }\end{array}$ & $\begin{array}{l}\text { Sale of asset } \\
\text { other than } \\
\text { inventory }\end{array}$ \\
\hline $\begin{array}{l}\text { Description } \\
\text { of Revenue }\end{array}$ & $\begin{array}{l}\text { Revenue } \\
\text { from sales }\end{array}$ & $\begin{array}{l}\text { Revenue } \\
\text { from fees } \\
\text { or services }\end{array}$ & $\begin{array}{l}\text { Revenue from } \\
\text { interest, rents, and } \\
\text { royalties }\end{array}$ & $\begin{array}{c}\text { Gain or } \\
\text { loss on } \\
\text { disposition }\end{array}$ \\
\hline \multicolumn{5}{|l|}{ Timing of } \\
\hline \multirow[t]{3}{*}{ Revenue } & $\begin{array}{c}\text { Date of } \\
\text { sale (date } \\
\text { of delivery }\end{array}$ & $\begin{array}{c}\text { Services } \\
\text { Performed } \\
\text { and } \\
\text { bitlable }\end{array}$ & $\begin{array}{l}\text { As time } \\
\text { passens or } \\
\text { assets are } \\
\text { used }\end{array}$ & $\begin{array}{c}\text { Date of sale } \\
\text { or trade-in }\end{array}$ \\
\hline & Tahapan Pengakuan Pendapatan dan Beban & \multicolumn{3}{|c|}{ Gambar 1} \\
\hline & \multicolumn{4}{|c|}{ Tabel 1} \\
\hline \multicolumn{5}{|c|}{ Perhitungan Pendapatan menggunakan Metode Kontrak Selesai Periode p } \\
\hline & \multicolumn{2}{|c|}{ Tahun } & \multicolumn{2}{|c|}{ Total } \\
\hline & \multicolumn{2}{|r|}{2016} & \multicolumn{2}{|c|}{ Rp. 657.264 .333} \\
\hline & \multicolumn{2}{|r|}{2017} & \multicolumn{2}{|c|}{ Rp 1.046.753.400 } \\
\hline & \multicolumn{2}{|r|}{2018} & \multicolumn{2}{|l|}{0} \\
\hline & \multicolumn{2}{|r|}{2019} & \multicolumn{2}{|c|}{$\operatorname{Rp} 2.183 .160 .740$} \\
\hline
\end{tabular}

\section{METODOLOGI PENELITIAN}

Metode analisis data yang digunakan oleh peneliti dalam penelitian ini yaitu menggunakan metode kualitatif. Dimana proses penelitian nanti dilakukan dengan cara sebagai berikut :

1. Melakukan observasi langsung ke objek penelitian untuk mengetahui gambaran umum perusahaan mengenai kegiatan perusahaan. Kemudian kebagian keuangan untuk mendapatkan laporan realisasi anggaran.
2. Mengumpulkan data-data yang berhubungan dengan penelitian baik data primer maupun data sekunder untuk dijadikan dasar acuan dalam penelitian tersebut.

3. Menganalisis apakah penerapan akuntansi pengakuan pendapatan yang ada dalam perusahaan sudah berjalan sesuai dengan prosedur yang seharusnya atau tidak.

4. Ditarik kesimpulan bahwa PT.Samudra Jaya Lestari dalam mengakui pendapatan proyek jangka panjang atau lebih dari 
periode akuntansi menggunakan metode kontrak selesai. Seharusnya sesuai PSAK No.34 PT.Samudra Jaya Lestari dalam mengakui pendapatan harus menggunakan metode persentase penyelesaian untuk menggambarkan laporan keuangan yang sesungguhnya.

\section{HASIL PENELITIAN DAN PEMBAHASAN}

Pengakuan pendapatan yang digunakan PT.Samudra Jaya Lestarimetode kontrak selesai berdasarkan kemajuan pengerjaan proyek dilapangan. Metode ini digunakan untuk sebagian proyek yang berlangsung lebih dari satu periode akuntansi (lebih dari satu tahun).

Proyek-proyek yang dikerjakan PT.Samudra Jaya Lestari ada yang selesai dalam satu periode akuntansi dan ada juga yang selesai dalam jangka waktu lebih dari satu periode akuntansi. Dalam melaksanakan proyeknya, PT.Samudra Jaya Lestari mengakui pendapatan dengan metode yang berbeda-beda setiap tahunnya.

Pada tahun 2016 PT.Samudra Jaya Lestari menggunakan metode kontrak selesai dalam mengakui pendapatan atas proyek Pembangunan Jembatan Sungai Semenung Kecamatan.Ulu Terawas yang berlangsung pada tanggal 22 Juni 2016 sampai 30

Desember 2016.

Pada tahun 2017 PT. Samudra Jaya Lestari menggunakan metode persentase penyelesaian dalam mengakui pendapatannya atas proyek Pembangunan SPAM Kecamatan Ulu Rawas (Dak Reguler Sarpras Penunjang Air Minum) yang berlangsung pada tanggal 08 Agustus 2016 sampai 15 Juni 2017 karena proyek tersebut berlangsung lebih dari satu periode akuntansi, serta untuk menggambarkan posisi keuangan perusahaan yang sebenarnya.

Pada tahun 2018 PT.Samudra Jaya Lestari menggunakan metode kontrak selesai dalam mengakui pendapatannya pada Proyek Pembangunan Jembatan Beton Desa Nanjungan Kecamatan Pendopo yang berlangsung pada tanggal 20 januari 2018 sampai 21 Februari 2019. Dimana dengan metode kontrak selesai pendapatan hanya dapat diakui pada saat kontrak tersebut telah diselesaikan. Dengan begitu pada tahun 2019 PT.Samudra Jaya Lestari tidak dapat mengakui pendapatan yang mengakibatkan PT.Samudra Jaya Lestari mengalami kerugian. Berikut adalah Laporan Pendapatan PT.Samudra Jaya Lestari selama tahun 20162019.

Tabel 2

Laporan Pendapatan Perusahaan Tahun 2016 - 2019 PT.Samudra Jaya Lestari

\begin{tabular}{|c|c|c|c|c|}
\hline Tahun & Nama Proyek & $\begin{array}{l}\text { Nilai Proyek } \\
\text { (Rp) }\end{array}$ & $\begin{array}{c}\text { Biaya } \\
\text { (Rp) }\end{array}$ & $\begin{array}{c}\text { Pendapatan } \\
\text { (Rp) }\end{array}$ \\
\hline 2016 & $\begin{array}{l}\text { Pembangunan Jembatan } \\
\text { Sungai Semenung } \\
\text { Kecamatan Ulu Trawas }\end{array}$ & 4.381 .762 .000 & 3.724 .497 .667 & 657.264 .333 .000 \\
\hline 2016 & $\begin{array}{ll}\text { Pembangunan } & \text { SPAM } \\
\text { Kecamatan Ulu } & \text { Trawas } \\
\text { (Dak Reguler } & \text { Sarpras } \\
\text { Penunjang Air Minum) }\end{array}$ & 6.978 .356 .000 & & 470.139 .030 \\
\hline 2017 & $\begin{array}{ll}\text { Pembangunan } & \text { SPAM } \\
\text { Kecamatan Ulu } & \text { Trawas } \\
\text { (Dak Reguler } & \text { Sarpras }\end{array}$ & & 3.263 .481 .430 & 574.614 .370 \\
\hline
\end{tabular}




\begin{tabular}{|l|l|l|l|l|}
\hline & Penunjang Air Minum) & & & \\
\hline 2018 & $\begin{array}{l}\text { Pembangunan Jembatan } \\
\text { Beton Desa Nanjungan } \\
\text { Kecamatan Pendopo }\end{array}$ & 12.842 .122 .000 & & 0 \\
\hline 2019 & $\begin{array}{l}\text { Pembangunan Jembatan } \\
\text { Beton Desa Nanjungan } \\
\text { Kecamatan Pendopo }\end{array}$ & & 10.915 .804 .000 & 1.926 .318 .000 \\
\hline
\end{tabular}

Sumber : Data diolah dari PT.Samudra Jaya Lestari

Dilihat pada tabel diatas, dengan menggunakan metode kontrak selesai PT.Samudra Jaya Lestari mengakui pendapatannya atas proyek Pembangunan Jembatan Sungai Semenung Kecamatan Ulu Rawas dengan nilai kontrak $\mathrm{Rp}$ 4.381.762.000 dan biaya yang digunakan dalam proyek tersebut sebesar 3.724.497.667 memperoleh pendapatan sebesar Rp. 657.264.333.

Pada tahun 2017 PT.Samudra Jaya Lestari mengakui pendapatan atas proyek Pembangunan SPAM Kecamatan Ulu Trawas ( Dak Reguler Sarpras Penunjang Air Minum) menggunakan metode persentase penyelesaian dengan nilai proyek sebesar Rp.6.978.356.000 dan biaya yang digunakan dalam proyek tersebut sebesar Rp 5.933.602.600 dengan memperoleh pendapatan sebesar Rp 1.046.753.400.

Pada tahun 2018 PT. Samudra Jaya Lestari tidak mengakui pendapatan (sama dengan nol) atas proyek Pembangunan Jembatan Beton Desa Nanjungan Kecamatan Pendopo dengan proyek Rp 12.842.122.000 karena proses pengerjaan proyek belum selesai di tahun 2018. Barulah pada tahun 2019 PT.Samudra Jaya Lestari mengakui pendapatan atas proyek tersebut menggunakan metode kontrak selesai dengan total pendapatan sebesar Rp1.926.318.000. Kelemahan penggunaan metode kontrak selesai pada tahun 2018-2019 adalah PT.Samudra Jaya Lestari tidak dapat mengakui dengan pasti laba bersih yang diperoleh karena pendapatan dilaporkan setelah kontrak selesai dikerjakan, kurang relevan karena pendapatan bersih perusahaan tidak mencerminkan hasil yang sesungguhnya.

Data penelitian PT.Samudra Jaya Lestari yang digunakan untuk menghitung pendapatan kontrak konstruksi dengan menggunakan metode kontrak selesai dan metode persentase penyelesaian yang sesuai dengan PSAK No.34 yang hubungannya dengan metode pengakuan pendapatan baik dengan metode kontrak selesai maupun metode persentase penyelesaian dan dalam penentuan laba atau rugi pada PT.Samudra Jaya Lestari adalah sebagai berikut :

Tabel 3

Rekapitulasi Data Proyek PT.Samudra Jaya Lestari Tahun 2016-2019

\begin{tabular}{|l|l|l|l|l|}
\hline \multirow{2}{*}{ Tahun } & \multicolumn{1}{|c|}{ Nama Kontrak } & \multirow{2}{*}{$\begin{array}{c}\text { Kontrak } \\
\text { Selesai }\end{array}$} & \multicolumn{2}{|c|}{ Persentase Penyelesaian } \\
\cline { 4 - 5 } & & Tahun 1 & Tahun 2 \\
\hline 2016 & Pembangunan Jembatan & $100 \%$ & & \\
& Sungai Semenung & & & \\
& Kecamatan Ulu Trawas & & & \\
\hline $2016-2017$ & Pembangunan SPAM & & $2016=45$ & $2017=55 \%$ \\
& Kecamatan Ulu Trawas & & $\%$ & \\
& (Dak Reguler Sarpras & & & \\
& Penunjang Air Minum & & & \\
\hline
\end{tabular}




\begin{tabular}{|l|l|l|l|l|}
\hline 2018-2019 & Pembangunan Jembatan & $100 \%$ & $\begin{array}{l}2018= \\
83,3 \%\end{array}$ & $2019=16,7 \%$ \\
& $\begin{array}{l}\text { Beton Desa Nanjungan } \\
\text { Kecamatan Pendopo }\end{array}$ & & & \\
\hline
\end{tabular}

Sumber : Data Diolah PT.Samudra Jaya Lestari

Dilihat dari tabel 3 yaitu tentang Rekapitulasi Kontrak Kerja PT.Samudra Jaya Lestari pada tahun 2016 atas proyek Pembangunan Jembatan Sungai Semenung Kecamatan Ulu Trawas yang berlangsung pada tanggal 22 Juni 2016 - 30 Desember 2016 PT.Samudra Jaya Lestari menggunakan metode kontrak selesai dalam mengakui pendapatannya.

Pada Tahun 2017 PT.Samudra Jaya Lestari menggunakan metode persentase penyelesaian dalam mengakui pendapatannya atas proyek Pembangunan SPAM Kecamatan Ulu Trawas (Dak Reguler Sarpras Penunjang Air Minum) yang berlangsung pada 08 Agustus 2016 - 15 Juni 2017.

Pada 12 Januari 2018- 11 Februari 2019 PT.Samudra Jaya Lestari mengakui pendapatannya menggunakan metode kontrak selesai atas proyek Pembangunan Jembatan Beton Desa Nanjungan Kecamatan Pendopo sehingga membuat PT.Samudra Jaya Lestari tidak mengakui keuntungannya pada tahun 2018 (sama dengan nol) seharusnya PT.Samudra Jaya Lestari menggunakan metode persentase penyelesaian karena proyek berlangsung dalam dua periode akuntansi, agar menggambarkan posisi keuangan perusahaan yang sebenarnya.

\section{KESIMPULAN}

Setelah dilakukan perhitungan pengakuan pendapatan dengan metode kontrak selesai dan persentase penyelesaian serta pengaruhnya terhadap laporan laba rugi PT.Samudra Jaya Lestari dan dapat ditarik kesimpulan antara lain sebagai berikut :

1. PT.Samudra jaya Lestari dalam menerapkan metode pengakuan pendapatan belum sesuai dengan PSAK No.34, dimana PT.Samudra Jaya Lestari menerapkan metode pengakuan pendapatan secara berubah-ubah yang tidak sesuai aturan menurut PSAK No.34 yaitu pada 2016 PT.Samudra Jaya Lestari menerapkan metode pengakuan pendapatan kontrak selesai dalam proyek yang berlangsung selama 7 bulan (satu periode akuntansi), kemudian pada 2017 PT. Samudra Jaya Lestari menggunakan metode persentase penyelesaian karena proyek berlangsung dalam 11 bulan (dua periode akuntansi) , Kemudian di 20182019 PT.Samudra Jaya Lestari menggunakan metode kontrak selesai padahal proyek berlangsung dalam dua periode akuntansi sehingga dalam pelaporan keuangannya mempengaruhi laba rugi perusahaan. Hal ini merupakan tindakan yang menyalahi standar akuntansi keuangan yang berlaku menurut PSAK No.34, jika kontrak berjangka satu periode akuntansi maka perusahaan dapat memakai metode kontrak selesai sedangkan untuk kontrak yang berjangka panjang perusahaan dapat menggunakan metode persentase penyelesaian dalam pencapaian akuntansi kontrak konstruksi yang andal dan akurat.

2. Pengungkapan pendapatan yang diterapkan PT.Samudra Jaya Lestari belum sesuai dengan PSAK No.34, dimana perusahaan menerapkan metode kontrak selesai dalam mengakui pendapatannya untuk proyek yang terjadi lebih dari satu periode. Sehingga laporan laba yang dihasilkan bersifat fluktuatif (naik turun) yaitu kondisi dimana perusahaan menjadi kecil pada suatu periode dan pendapatan perusahaan menjadi besar pada periode lain saat pengerjaan proyek telah selesai.

3. Penerapan metode kontrak selesai yang digunakan perusahaan akan berdampak dalam laporan keuangan perusahaan dimana metode kontrak selesai yang 


$\begin{array}{lrr}\text { digunakan } & \text { perusahaan } & \text { tidak } \\ \text { mencerminkan } & \text { keadaan } & \text { yang }\end{array}$
sesungguhnya pada perusahaan sehingga menyebabkan pendapatan yang diterima perusahaan tidak sewajarnya, sedangkan dengan penggunaan metode persentase penyelesaian mencerminkan kondisi keuangan yang sesungguhnya terjadi yang ada diperusahaan tersebut selain itu metode persentase penyelesaian menunjukkan penyelesaian proyek yang sesungguhnya terjaadi di perusahaan.

\section{SARAN}

Berdasarkan uraian teoritis yang telah diungkapkan sebelumnya dan berdasarkan data-data yang diperoleh sebuhungan dengan kegiatan penelitian yang dilakukan pada PT.Samudra Jaya Lestari, maka peneliti dapat mencoba memberikan saran yangsekiranya dapat bermanfaat bagi pihak-pihak yang berkepentingan, seperti:

1. Bagi PT.Samudra Jaya Lestari sebaiknya dalam melakukan pengakuan dan pengungkapan atas pendapatan dan beban pada PT.Samudra Jaya Lestari melakukan hal konsistensi dengan berpedoman pada Pernyataan Standar Akuntansi Keuangan No.34 Tentang Kontrak Konstruksi dan ada baiknya menerapkan metode persentase penyelesaian dalam mengakui pendapatan setiap tahunnya agar laporan laba rugi yang dihasilkan menjadi lebih akurat dan sesuai dengan Pernyataan Standar Akuntansi Keuangan No.34 Tentang Kontrak Konstruksi. Dengan demikian diharapkan laporan laba rugi yang disajikan oleh perusahaan dapat menjadi pemberi informasi yang kemudian dapat digunakan untuk pengambilan keputusan yang tepat bagi perusahaan.

2. Bagi peneliti dapat menambah referensi dan memperluas ilmu pengetahuan lebih dalam mengenai akuntansi pendapatan kontrak konstruksi

3. Bagi peneliti selanjutnya dapat menggabungkan beberapa faktor lain tentang akuntansi pendapatan konstruksi yang diharapkan hasilnya lebih baik lagi

\section{DAFTAR PUSTAKA}

[1] Ikatan Akuntan Indonesia. 2015. Peryataan Standar Akuntansi Keuangan. No.34 Revisi 2015. Jakarta: Ikatan Akuntan Indonesia.

[2] Ratunuman, Sisilia Merry. 2015. Analisis Pengakuan pendapatan dengan Penyelesaian dalam penyajian laporan keuangan PT.Pilar Dasar. Jurnal Emba Vol. I No. 3. Tahun 2013.

[3] Irsyad dan Dwi Martani. 2020. Pendapatan Kontrak Konstruksi PSAK 34. Slide OCW Universitas Indonesia. Akuntansi Keuangan 2 - Departemen Akuntansi FEUI. Diakses pada 21 April 2020 pukul 10.00 WIB. https://ocw.ui.ac.id/pluginfile.php/198/mo d resource/content/0/AK2\%20Pertemuan $\% 2010 \% 20 \mathrm{Pengakuan} \% 20 \mathrm{Pendapatan} \% 2$ 0Kontrak\%20Konstruksi.pdf

[4] Kieso, Donald E., Jerry J. Weygant, and Terry D. Warfield 2007, Akuntansi Intermediate,Jilid 1,2 Edisi ke duabelas Terjemahan, Penerbit Erlangga, Jakarta

[5] Rahayu dan Kardinal. 2013. Analisis Pengakuan Pendapatan Jasa Konstruksi Pada CV. Samudera Konstruksi Palembang Berdasarkan PSAK No. 34. https://docplayer.info/29751378-Analisispengakuan-pendapatan-jasa-konstruksipada-cv-samudera-konstruksi-palembangberdasarkan-psak-no-34.html

[6] Hasnawati; Firman Menne dan chahyono. 2016. Analisis Pengakuan Pendapatan Kontrak Konstruksi Berdasarkan Psak 34 Pada Cv Primadonna Di Kecamatan Masamba Kabupaten Luwu Utara. Jurnal Riset Edisi II Unibos Makassar Vol 1, No. 013. 